\title{
1. Introduction: the rise of political hate speech online
}

\section{THE STATUS OF POLITICAL HATE SPEECH IN EUROPE}

This book deals with legal-informatics arguments related to political hate speech online. In essence, this work is an interdisciplinary analysis of political hatred on social network platforms.

Specific consideration will be dedicated to episodes touching upon the issues of migrants, ${ }^{1}$ refugees and other minority groups that are usually identified online as targets of hate speech, prejudice and discrimination. Similar groups are repeatedly attacked during political debates and electoral disputes in Europe, especially on politicians' own web pages, profiles and accounts. Likewise, some politicians encourage their followers to hate the persons they put at the centre of their political debate, and the people who defend the victims or criticize the tones used.

While the phenomenon of online political hatred is disseminated all over the world, it takes unique forms in European countries. This essentially results from two circumstances.

First, the historical, political and legal tradition in Europe regarding these arguments is very peculiar in comparison with the common global frame of reference and, in particular, with the legal tradition of the United States of America. ${ }^{2}$ The US doctrine and case law will of course be a constant point of reference during our analysis. This is the land in which technology companies, platforms and digital startups process the largest amount of content in the world, including European citizens' digital communications and online speech. European users' data are today stored almost exclusively on WhatsApp, Twitter, Instagram, YouTube, Facebook, Gmail and Hotmail servers.

\footnotetext{
1 Concerning, generally, international and State laws - and best practices - for migrants, see Mary Crock and Lenni Benson (eds), Protecting Migrant Children (Edward Elgar 2018).

2 See Chapter 3, Paragraph 4.
} 
But the approach taken in the US legal framework is libertarian, according to the principles of the First Amendment to the Constitution. The clear choice in the US not to have law, codes or statutes against hate speech was different from that taken by every other liberal democracy. In this land, in fact, possible regulation of hate speech is seen not only as a violation of the First Amendment, but also as damaging to a free society. ${ }^{3}$

Second, in comparison to the US, there was an evident delay regarding the diffusion of new technologies in the Old Continent. This is why major legal problems, including the tackling of hate speech content, were faced at a later time.

The European legal framework on the issues of digital society, the digital single market, platforms' responsibility and regulation of hate online is still in transition, with daily reform proposals - and also official recommendations, resolutions, guidelines and ethical charts - coming from the European Union, from the Council of Europe and from specific countries. ${ }^{4}$ This has led to what are at present very heterogeneous - and often clashing - attitudes to this issue among the various European states. ${ }^{5}$

The fact that political discussions can give rise to verbal violence and harsh tones is not, of course, a novelty brought about by new technologies. However, specific analysis of tones, topics, actions and attacks currently experienced online in Europe and involving political themes is particularly interesting and is mostly needed due to the relocation online of what are typical political propaganda activities.

Today there is a close connection between online hate, the idea of the digital environment, the concept of democracy and, most of all, the very idea of citi-

3 For a very authoritative, critical introduction to the problem of hate speech in the North American legal landscape, see Jeremy Waldron, The Harm in Hate Speech (Harvard University Press 2012). For an introduction to hate speech issues in the USA legal tradition, see Richard Delgado and Jean Stefancic, Understanding Words That Wound (Routledge 2019). For a precise description of the basics of the American free speech doctrine, see James Weinstein, Hate Speech, Pornography, And Radical Attacks On Free Speech Doctrine (Routledge 2018). For a 'celebration' of the First Amendment, see Geoffrey R Stone and Lee C Bollinger (eds), The Free Speech Century (Oxford University Press 2019).

4 For a first comparison between the USA and European legal frameworks, see, in Italian, Giovanni Ziccardi, L'odio online (Raffaello Cortina Editore 2016). For an analysis of racist speech as interpreted in USA and Europe see Erik Bleich, The Freedom to Be Racist?: How the United States and Europe Struggle to Preserve Freedom and Combat Racism (Oxford University Press 2011).

5 See Chapter 2, Paragraph 6. 
zenship - and civic daily life - in our society. ${ }^{6}$ In particular, the issue of online hatred today relates broadly to three different aspects of political life. ${ }^{7}$

The first point involves politics in a broad sense: the main issue is whether it could be appropriate or not for legislators to intervene to regulate the new political framework and related activities generated online.

The second point is connected directly to politicians as individuals. In this case, legal issues involve the politician seen as the target of hate messages, or, vice versa, as the author of hatred or incitement to hatred (or both).

The third point is strictly connected to current political, social and domestic affairs, and to the daily chronicles of such. ${ }^{8}$ This issue regards the close correlation between political hatred online and what is happening in our society such as, for example, the frequent migrant crises in Europe ${ }^{9}-$ and refers also to the use of political propaganda as a subtle - and, apparently, neutral - method of fomenting hatred in society. ${ }^{10}$ This is why hate speech is an issue that cannot be ignored by political forces. Hate speech concerning ethnic, religious, racist and sexual arguments has, in fact, a strong ability to alter both the central and the local balance of a state, to directly influence the behaviour of citizens, and, ultimately, to threaten the stability of a democracy. ${ }^{11}$

At the same time, political forces daily convey, through online speeches, web documents, 'live streaming' smartphone transmissions, programmes, rallies and interviews, messages that undoubtedly target a great amount of hate speech at ethnic, religious and sexual minorities; ${ }^{12}$ immigrants; and other vulnerable groups. In recent years there has been a transversal enlargement of this, moving from such discourses mostly being seen in far right and extremist

6 Concerning the theory that free expression must be safeguarded not just as an individual right, but as an essential attribute of democratic citizenship, see Eric Heinze, Hate Speech and Democratic Citizenship (Oxford University Press 2017).

7 The following three points are exposed, more precisely, in Giovanni Ziccardi, Tecnologie per il potere (Raffaello Cortina Editore 2019).

$8 \quad$ See Chapter 7.

9 Regarding, inter alia, the increase of hatred against migrants in Europe, see Stavros Assimakopoulos, Fabienne H Baider and Sharon Millar, Online Hate Speech in the European Union: A Discourse-Analytic Perspective (Springer 2017).

10 Concerning this aspect, see Chapter 9.

11 Regarding the complex relationship between technologies and political activity in the social network era, see, in Italian, Giovanni Ziccardi, Tecnologie per il potere (Raffaello Cortina Editore 2019). Concerning the relationship between free speech and the online world, see Timothy Garton Ash, Free Speech: Ten Principles for a Connected World (Atlantic Books 2016).

12 Regarding hate speech issues related to gender, see Debbie Ging and Eugenia Siapera (eds), Gender Hate Online: Understanding the New Anti-Feminism (Palgrave Macmillan 2019). 
parties to the entry of these themes also into the rhetoric of the so-called mass parties. ${ }^{13}$

Today, political discourses permeated with hate have a great impact on a section of the electorate and, as a consequence, have seen increased consensus and evident electoral success. Political hatred online has become an instrumental factor in increasing the voter base of a given party. The political and academic debate must therefore involve what is allowed and what is forbidden in extreme political discourses, and what cannot be permitted for the protection of citizens or for the security of the state.

There is also an urgent need for awareness in the political world about the fact that, due to their position, politicians who speak online should take greater responsibility. This is because their diffusive power of prejudice against, for example, a targeted group is very high thanks to the resonance chamber provided by the mass media and the online platforms. These are propaganda tools that politicians can easily use at any time, and at no cost.

In other words, there is a sort of position of authority that puts the politician in a condition of strength, altering the balance - just as in typical bullying cases - so that the hate speech can have an impact on others: potential agents who feel supported by politicians and, consequently, think they may act in the same way. ${ }^{14}$

This means that, in a perfect world, politicians should ensure that they use tones and discourses that do not convey expressions of hatred and, moreover, should openly criminalize such method of expression. They should also oppose the possibility that such speech could become part of the democratic process, alongside any widespread tolerance of similar tones. ${ }^{15}$ Unfortunately, as we will see below, this important role formerly played by parties and individual politicians is now disappearing from all European countries.

The point from which this study begins is the idea that political hate speech in Europe manifests some original connotations with respect to other continents and, especially, the American tradition. This implies the need for an approach that on the one hand is solidly rooted in European history (and in the

13 Regarding the far-right political forces in the international and European community, see Natalie Alkiviadou, The Far-Right in International and European Law (Routledge 2019).

14 Concerning the harms of hate speech, see Mary Kate McGowan, Just Words: On Speech and Hidden Harm (Oxford University Press 2019).

15 Concerning the connections between political discourses and hate speech, see Thomas Brudholm and Birgitte Schepelern Johansen (eds), Hate, Politics, Law: Critical Perspectives on Combating Hate (Oxford University Press 2018). 
recent tragedies in the continent), and on the other is always attentive to what happens overseas, especially in Washington and Silicon Valley. ${ }^{16}$

This approach creates very obvious legal conflicts between Europe and the United States. We will see that there are concerns in the US legal and academic world regarding the activity of the European Union and specific states (especially Germany, France, the United Kingdom and Italy) in four areas: antitrust law, data protection law, copyright law and, now, hate speech law. The danger highlighted by some American scholars is that in these areas there is a sort of 'Europe-ization' of international legal regulation which comes into strong contrast with the North American constitutional tradition.

In the following pages we will try to carefully identify these moments of conflict, and we will suggest possible solutions.

\section{HATE SPEECH DURING THE EUROPEAN ELECTIONS}

\subsection{Political Ideology as the Basis of Hateful Comments}

In recent European research conducted in a typical preelection framework, several preliminary interesting points of debate were identified with great accuracy. These remarks are very useful, at the beginning of our study, to draw and characterize an initial, generic picture of online political hatred in Europe. ${ }^{17}$

The authors of the report preliminarily affirm that, in Europe, political ideology is the first and most important determinant of rude, offensive or hateful comments on social media. This statement, which opens the report, is the result of the findings of a four month project conducted by journalists from Deutsche Welle and other news organizations in four European countries: France, Germany, Italy and Switzerland. The project rated more than 40,000 comments posted on the Facebook and Twitter accounts of a random sample of 320 politicians in the time range 21 February 2018-21 March 2018.

If we broadly intend the locution 'political ideology', following the definition elaborated by Michael Freeden, as a combination of ideas, beliefs, values and opinions, exhibiting a recurring pattern, 'that competes deliberately as

16 Concerning the importance of the Silicon Valley in the global digital economy see, in French, Éric Sadin, La Silicolonisation du Monde (Les Éditions L'échappée 2016).

17 See Alison Langley and Rania Wazir, 'Want to quell hate speech on social media? Talk to right-wing politicians' Deutsche Welle (Bonn-Berlin, 29 May 2018) $<$ https://www.dw.com/en/want-to-quell-hate-speech-on-social-media-talk-to-right -wing-politicians/a-43934171> accessed 8 August 2019. 
well as unintentionally over providing plans of action for public policy making in an attempt to justify, explain, contest, or change the social and political arrangements and processes of a political community', ${ }^{18}$ it is clear that we refer in particular to those actors in the online discussion with opposing political ideologies, and, more specifically, to elected officials, opinion leaders, parties, media organizations and nonprofit groups.

In election times in Europe, where there is a lot of confusion about ideologies and values and where the traditional distinctions between 'right' and 'left' are often questioned, this preliminary issue presents itself as a very complex problem for the interpreter to solve.

\subsection{The Use of Hate Speech by Rightwing and Populist Politicians}

Second, the authors of the report underline that comments posted on rightwing and populist politicians' Facebook and Twitter feeds generated the greatest number of offensive comments directed at elected officials from the centre or the left. Moreover, prominent female politicians in France and Italy were the target of most hurtful speech. Therefore, online political hatred seems to take two very specific directions: from extreme parties to centre and left parties, and towards political women, without distinction of political affiliations.

In our opinion, alongside verbal violence from far right parties that use certain tones by tradition, there has also been an increase in violence in the tone of parties belonging to areas that are usually quieter from this point of view. Perhaps this came about through adaptation of political actions to the now common tone of the political debate, thus renouncing the quality and correctness of the political dialogue that had been typical of those cultural and political areas.

\subsection{How Might Good Politics Help?}

In a third point, the authors of the study state that hate speech was less prevalent than is generally assumed, and that a good way of controlling hate might be through leading politicians' actions specifically against online hate. In this case, politicians could act as a useful means to contain hatred.

This statement, in our opinion, is interesting: political hatred 'numerically calculated' appears to be less serious, as a phenomenon, than is commonly

18 This definition is taken from Michael Freeden, 'Ideology: Political Aspects', The International Encyclopedia of the Social \& Behavioral Sciences (2001, 7174-7177) $<$ https://www.sciencedirect.com/science/article/pii/B0080430767011542\#!> accessed 8 August 2019 (emphasis added). 
perceived; at the same time, it appears to be much more visible than correct and calm political discourse.

\subsection{The Polarization of the Political Debate}

The fourth issue involves the fact that politicians have become more polarized, and that political confrontation between parties and persons today is characterized by extreme conflict that leads, inevitably, to an increase in negative tone and to a constant, elementary fight (and dialogue) between the parties. ${ }^{19}$ The most common statement seen on political social networks and profiles is 'you are with me or you are against me'.

At the same time, states are searching for good legal methods to control this polarization, punishing incendiary speech, often trying to oblige technological platforms to remove posts and contents.

Unfortunately, in our opinion, the phenomenon of polarization is affecting not only the world of political dialogue but also much other content, and many other topics, circulating on the net. On social networks, fiery and polarized discussions on any theme have become habitual: reviews of restaurants; comments on sport events, singers, actors and showmen; even discussions of the death of a well-known person.

\subsection{Centre and Leftwingers between Hate and 'Troll Magnets'}

The findings of the study demonstrate that posts on rightwing and populist politicians' feeds generated more offensive comments than those on the feeds of elected officials on the centre or the left. In particular, 6 per cent of the posts on French and Italian politicians were harsh; a smaller percentage of objectionable remarks were directed at Swiss and German politicians (4.8 and 4.5 per cent respectively). Centre and left-leaning politicians seem to be 'troll magnets', and steadily attract hatred.

\subsection{Elected Officials as a Common Target for Hate}

At the same time, offensive speech tends to personally attack mainstream elected officials. The study presents specific examples of politicians who received a high amount of hate, all of whom were from centre or left-leaning parties. The list includes Beatrice Lorenzin (Popular Alternative) and Davide Mattiello (Partito Democratico) in Italy, Ulla Jelpke (Left Party) in Germany and Aurore Berge (En Marche) and Eric Alauzet (Green Party) in France.

19 See Chapter 8, Paragraph 1. 
Germany's Michael Brand (CDU) was attacked online after writing that he was 'disgusted' that Alternative für Deutschland politicians visited officials in Syria after the Assad government used chemical weapons; ${ }^{20}$ in Italy, several attacks were the consequence of discussions related to provaccine norms. Laura Boldrini, in Italy, has been the subject of hate campaigns that have lasted entire years. The same has happened to Maria Elena Boschi. In Iceland, a sensational case concerned Freyja Haraldsdóttir, a disabled woman and famous disability rights activist. ${ }^{21}$

\subsection{Countering Illegal Political Online Speech on the Digital Platforms}

According to this point of the study, the report data demonstrated overwhelmingly that a great part of political discourse with politicians on digital platforms is polite. This means that the control system operated by large platforms is probably efficient (in particular, the work cites the European Union's 2016 Code of Conduct on Countering Illegal Hate Speech Online), ${ }^{22}$ but it is very difficult to understand how much content is actually removed, since the platforms' activity on this point is not transparent.

\subsection{The Growth of Interpersonal Hate between Citizens}

On the other side, the authors of the study underline that the rules aimed at combating hate speech online seem to be ineffective in getting people to speak nicely with one another. Far right politicians see efforts to temper their language as suppression of freedom of speech; populists attract support by stirring up emotion and fear, and data shows that populists appear to tolerate poisonous posts and memes. In all European countries, according to the study, personal attacks between politicians using fake news, photo montages and direct insults are very common.

20 See Guy Chazan, 'Germany's AfD sparks outrage over links to Syrian regime' Financial Times (Berlin, 7 March 2018) <https://www.ft.com/content/1fb2eb4a-21f1 -11e8-9a70-08f715791301> accessed 16 August 2019.

${ }_{21}$ See, on this point, Chapter 7, Paragraph 7.

22 As reported on the pages of the institutional web site of the European Commission, the Code of Conduct was drafted 'To prevent and counter the spread of illegal hate speech online, in May 2016, the Commission agreed with Facebook, Microsoft, Twitter and YouTube a "Code of conduct on countering illegal hate speech online". In the course of 2018, Instagram, Google+, Snapchat and Dailymotion joined the Code of Conduct. Jeuxvideo.com joined in January 2019'. See $<$ https://ec.europa .eu/info/policies/justice-and-fundamental-rights/combatting-discrimination/racism -and-xenophobia/countering-illegal-hate-speech-online_en> accessed 12 August 2019. 
We also noticed very frequent attacks against other users who intervene to defend the victims, to publicly demonstrate solidarity or simply to report the truth when a politician spreads fake news. Often, groups of users are fomented and guided by the politician himself to attack subjects who have exposed themselves on social networks with unwelcome messages or considerations.

\subsection{Other Content of Politicians' Comments}

The study also highlights some virtuous conduct. Some politicians, for example, try to tone down, or not respond, to insults, or use humour to smooth out the controversy. In the report there is an interesting citation of the activities of Natalie Ricki (of Switzerland's SVP), who kept her Twitter feed 'civil' by posting fun comments (such as a picture of her riding a train to parliament with a member of another party) alongside more serious policy statements.

Lastly, politicians who posted fearful and emotional comments tended to receive more offensive comments, especially directed at groups (immigrants, Muslims, feminists and mainstream media); the same happens to single users.

\subsection{Hate against Immigrants, and Sexism}

Finally, the report underlines that in Germany, resentment of immigrants dominated the debate on social media; in France, sexist comments were most common; and in Italy, both anti-immigration rhetoric and sexism were prevalent. In Switzerland, especially violent comments were made about African immigrants and 'lefty' politicians and electors.

These arguments constituting hate speech, we shall see, are common in all European states, with slight variations related to the historical and political tradition of the individual states.

\section{A BRIEF INTRODUCTION TO HATE SPEECH AND LAW}

\subsection{UDHR, ICCPR, HR Committee and European Sources}

Although our study is dedicated to online hatred in particular, the basic principles from which to move are common, and concern hatred in general.

Most of the topics covered in this study, except when specifying the provisions - or decisions - of specific countries, are often related to the framework drawn by international law on the subject of hate speech, freedom of expression and equality in society. 
The nonprofit organization Article 19, at the beginning of most of its main reports regarding the state of hate speech in single European countries, ${ }^{23}$ usually draws with great precision a brief legal history of the evolution of international and European legislation on the subject. Given the fact that these norms are references that we will encounter throughout the study, it is appropriate to identify and clarify them at this point of the discussion.

The first source of reference is, inevitably, Article 19 of the Universal Declaration of Human Rights (UDHR), which was implemented and put into force thanks to Article 19 of the International Covenant on Civil and Political Rights (ICCPR).

The text of Article 19 of the UDHR, as drafted on 10 December 1948, is as follows:

Everyone has the right to freedom of opinion and expression; this right includes freedom to hold opinions without interference and to seek, receive and impart information and ideas through any media and regardless of frontiers.

The text of Article 19 of ICCPR, which was drafted on 16 December 1966 but entered into force on 23 March 1976, is as follows:

1. Everyone shall have the right to hold opinions without interference.

2. Everyone shall have the right to freedom of expression; this right shall include freedom to seek, receive and impart information and ideas of all kinds, regardless of frontiers, either orally, in writing or in print, in the form of art, or through any other media of his choice.

3. The exercise of the rights provided for in paragraph 2 of this article carries with it special duties and responsibilities. It may therefore be subject to certain restrictions, but these shall only be such as are provided by law and are necessary:

(a) For respect of the rights or reputations of others;

(b) For the protection of national security or of public order (ordre public), or of public health or morals.

A second, fundamental legal source cited in Article 19 reports is the General Comment of the United Nations Human Rights Committee (HR Committee) n. 34 on Article 19 of 12 September 2012 ('Freedoms of opinion and expression,

23 See, for example, Article 19, Austria: Responding to 'hate speech' (Report, 2018) <https:/www.article19.org/wp-content/uploads/2018/09/Austria-Responding-to -Hate-Speech-.pdf $>$ accessed 5 August 2019; Article 19, Hungary: Responding to 'hate speech' (Report, 2018) <https://www.article19.org/wp-content/uploads/2018/03/ Hungary-Responding-to-'hate-speech'-WEB-v2.pdf> accessed 5 August 2019; Article 19, Poland: Responding to 'hate speech' (Report, 2018) < https://www.article19.org/wp -content/uploads/2018/04/Poland-Hate-Speech.pdf> accessed 5 August 2019. 
CCPR/C/GC/34, 12 September 2011'). ${ }^{24}$ In particular, the HR Committee has specified that freedom of opinion and expression also extends to expressions that people could find offensive and discriminatory, and to online media. ${ }^{25}$

Paragraphs 11 and 12 of the General Comment, included in the Title 'Freedom of Expression', are the most interesting in our context. The text of Paragraph 11 and Paragraph 12 is as follows (emphasis added):

11. Paragraph 2 requires States parties to guarantee the right to freedom of expression, including the right to seek, receive and impart information and ideas of all kinds regardless of frontiers. This right includes the expression and receipt of communications of every form of idea and opinion capable of transmission to others, subject to the provisions in article 19, paragraph 3 , and article 20 . It includes political discourse, commentary on one's own and on public affairs, canvassing, discussion of human rights, journalism, cultural and artistic expression, teaching, and religious discourse. It may also include commercial advertising. The scope of paragraph 2 embraces even expression that may be regarded as deeply offensive, although such expression may be restricted in accordance with the provisions of article 19, paragraph 3 and article 20 .

12. Paragraph 2 protects all forms of expression and the means of their dissemination. Such forms include spoken, written and sign language and such non-verbal expression as images and objects of art. 23 Means of expression include books, newspapers, pamphlets, posters, banners, dress and legal submissions. They include all forms of audio-visual as well as electronic and internet-based modes of expression.

In this general framework, however, a state may exceptionally limit some rights, because the right to freedom of expression is 'fundamental' but not 'absolute'. ${ }^{26}$

There is a three part test with strict requirements that must characterize the limitation of rights, which can be derived from Paragraph 3 of Article 19 of ICCPR. In particular, the limitation must be:

First: provided for by law. This means that any law or regulation 'must be formulated with sufficient precision to enable individuals to regulate their conduct accordingly', ${ }^{27}$

Second: in pursuit of a legitimate aim. This 'legitimate aim' is 'listed exhaustively as: respect of the rights or reputations of others; or the protection

24 See Article 19, Austria: Responding to 'hate speech' (Report, 2018, 5 and 50) $<$ https://www.article19.org/wp-content/uploads/2018/09/Austria-Responding-to-Hate -Speech-.pdf $>$ accessed 5 August 2019.

25 ibid, 9.

26 ibid, 9.

27 ibid, 9 (emphasis added). 
of national security or of public order (ordre public), or of public health or morals'. ${ }^{28}$

Third: necessary in a democratic society. This aspect requires the state to demonstrate, in a specific and individualized manner, "the precise nature of the threat, and the necessity and proportionality of the specific action taken, in particular by establishing a direct and immediate connection between the expression and the threat'. ${ }^{29}$

A third important legal source is Article 20 of ICCPR, especially Paragraph 2. In this norm, we can find an explicit punishment of incitement to discrimination, hostility or violence, stating that it must be prohibited by law. ${ }^{30}$

The text of Article 20 of ICCPR is as follows:

1. Any propaganda for war shall be prohibited by law.

2. Any advocacy of national, racial or religious hatred that constitutes incitement to discrimination, hostility or violence shall be prohibited by law.

A fourth source cited in Article 19 reports, which operates this time at the European level, is Article 10 of the European Convention on Human Rights, a norm that protects freedom of expression in a similar way to Article 19 of the ICCPR, with the possible limitations included in Paragraph 2 of Article $10 .{ }^{31}$

The text of Article 10 on freedom of expression is as follows (emphasis added):

1. Everyone has the right to freedom of expression. This right shall include freedom to hold opinions and to receive and impart information and ideas without interference by public authority and regardless of frontiers. This Article shall not prevent States from requiring the licensing of broadcasting, television or cinema enterprises.

2. The exercise of these freedoms, since it carries with it duties and responsibilities, may be subject to such formalities, conditions, restrictions or penalties as are prescribed by law and are necessary in a democratic society, in the interests of national security, territorial integrity or public safety, for the prevention of disorder or crime, for the protection of health or morals, for the protection of the reputation or rights of others, for preventing the disclosure of information received in confidence, or for maintaining the authority and impartiality of the judiciary.

ibid, 9 .

ibid, 9 (emphasis added).

ibid, 9.

ibid, 10 . 
In the European Union legal framework, the right to freedom of expression and information is guaranteed in Article 11 of the Charter of Fundamental Rights of the European Union. ${ }^{32}$ The text of this Article is as follows:

1. Everyone has the right to freedom of expression. This right shall include freedom to hold opinions and to receive and impart information and ideas without interference by public authority and regardless of frontiers.

2. The freedom and pluralism of the media shall be respected.

\subsection{The Right to Equality and Nondiscrimination}

A second very important aspect, with regard to international sources, is that of right to equality and nondiscrimination. ${ }^{33}$

In the UDHR, these rights are stated in Articles 1,2 and 7. The text of the Articles is as follows:

Article 1

All human beings are born free and equal in dignity and rights. They are endowed with reason and conscience and should act towards one another in a spirit of brotherhood.

\section{Article 2}

Everyone is entitled to all the rights and freedoms set forth in this Declaration, without distinction of any kind, such as race, colour, sex, language, religion, political or other opinion, national or social origin, property, birth or other status. Furthermore, no distinction shall be made on the basis of the political, jurisdictional or international status of the country or territory to which a person belongs, whether it be independent, trust, non-self-governing or under any other limitation of sovereignty.

\section{Article 7}

All are equal before the law and are entitled without any discrimination to equal protection of the law. All are entitled to equal protection against any discrimination in violation of this Declaration and against any incitement to such discrimination.

These principles took legal force in Articles 2, Paragraph 1 and 26 of the ICCPR. The text of the Articles is as follows:

Article 2

1. Each State Party to the present Covenant undertakes to respect and to ensure to all individuals within its territory and subject to its jurisdiction the rights recognized in the present Covenant, without distinction of any kind, such as

\footnotetext{
ibid, 10.

ibid, 10 .
} 
race, colour, sex, language, religion, political or other opinion, national or social origin, property, birth or other status.

2. Where not already provided for by existing legislative or other measures, each State Party to the present Covenant undertakes to take the necessary steps, in accordance with its constitutional processes and with the provisions of the present Covenant, to adopt such laws or other measures as may be necessary to give effect to the rights recognized in the present Covenant.

3. Each State Party to the present Covenant undertakes:

(a) To ensure that any person whose rights or freedoms as herein recognized are violated shall have an effective remedy, notwithstanding that the violation has been committed by persons acting in an official capacity;

(b) To ensure that any person claiming such a remedy shall have his right thereto determined by competent judicial, administrative or legislative authorities, or by any other competent authority provided for by the legal system of the State, and to develop the possibilities of judicial remedy;

(c) To ensure that the competent authorities shall enforce such remedies when granted.

They took legal force in Articles 2 (1) and 26 of the ICCPR. The text of Article 26 is as follows:

Article 26

All persons are equal before the law and are entitled without any discrimination to the equal protection of the law. In this respect, the law shall prohibit any discrimination and guarantee to all persons equal and effective protection against discrimination on any ground such as race, colour, sex, language, religion, political or other opinion, national or social origin, property, birth or other status.

At European level, the European Convention prohibits discrimination in Article 12 and more widely in Protocol 12. Article 14 on the prohibition of discrimination has the following text:

The enjoyment of the rights and freedoms set forth in this Convention shall be secured without discrimination on any ground such as sex, race, colour, language, religion, political or other opinion, national or social origin, association with a national minority, property, birth or other status.

The text of Article 1 of Protocol 12, on the general prohibition of discrimination, is as follows:

1. The enjoyment of any right set forth by law shall be secured without discrimination on any ground such as sex, race, colour, language, religion, political or other opinion, national or social origin, association with a national minority, property, birth or other status.

2. No one shall be discriminated against by any public authority on any ground such as those mentioned in paragraph 1. 


\subsection{Three Generic Categories of Hate Speech}

The authors of the Article 19 reports, after their analysis of the European regulatory framework, correctly divide hate speech into three categories with peculiar characteristics. These characteristics differ according to the response that the international human rights system requires from the specific states. ${ }^{34}$

The three categories are:

Prohibited hate speech. This category includes severe forms of hate speech that 'international law requires States to prohibit, including through criminal, civil, and administrative measures, under both international criminal law and Article 20(2) of the ICCPR' ${ }^{35}$

This category, in our opinion, is quite clear when it is indicated in supranational provisions but becomes more difficult to interpret in the implementing regulations of individual states, because not all the local norms literally incorporate the original expressions.

Hate speech prohibited by single states. This category includes other forms of hate speech that 'States may prohibit to protect the rights of others under Article 19(3) of the ICCPR, such as discriminatory or bias-motivated threats or harassment' ${ }^{36}$

In this case, greater freedom is given to individual states; depending on the context, either a restrictive interpretation may be adopted or there may even be extension to cases not explicitly foreseen.

Lawful hate speech. This category includes hate speech that is 'lawful and should therefore be protected from restriction under Article 19(3) of the ICCPR, but which nevertheless raises concerns in terms of intolerance and discrimination, meriting a critical response by the State'. ${ }^{37}$

Even in this case, it is the state that decides what is legal speech and what is not.

\subsection{The Prohibition of Hate Speech}

Concerning the obligation for a state to prohibit certain expressions of hate, the authors of Article 19 reports highlight the combination of Paragraph 2 of Article 20 of the ICCPR, General Comment n. 34 of the HR Committee (Paragraph 52) and the necessity to always meet the strict conditions set out in Paragraph 3 of Article 19. ${ }^{38}$

\footnotetext{
ibid, 10 .

ibid, 10 (emphasis added).

ibid, 10 (emphasis added).

ibid, 10 (emphasis added).

ibid, 11.
} 
The text of Paragraph 52 of the General Comment is as follows:

52. It is only with regard to the specific forms of expression indicated in article 20 that States parties are obliged to have legal prohibitions. In every case in which the State restricts freedom of expression it is necessary to justify the prohibitions and their provisions in strict conformity with article 19.

Authors of Article 19 reports correctly cite the Rabat Plan of Action as a source of important interpretative lines for the implementation of Paragraph 2 of Article 20 of the ICCPR.

In particular, it is important to do the following:

Analyse the type of incitement. According to the authors, prohibitions should only focus on the advocacy of 'discriminatory hatred that constitutes incitement to hostility, discrimination, or violence, rather than the advocacy of hatred without regard to its tendency to incite action by the audience against a protected group' ${ }^{39}$

Unfortunately, establishing the limits of the incitement is complex; concerning this aspect, the individual national courts elaborate parameters that often differ (for example, in the evaluation of the necessity or otherwise of a concrete violent action).

Perform a six-part threshold test. This approach could be useful to 'assist in judicial assessments of whether a speaker intends and is capable of having the effect of inciting their audience to violent or discriminatory action through the advocacy of discriminatory hatred'.

The six factors to be considered are:

(1) Context: the expression should be considered within the political, economic and social context 'prevalent at the time it was communicated, for example the existence or history of conflict, existence or history of institutionalised discrimination, the legal framework, and the media landscape'. The first step is, therefore, to take into consideration the social context in general, both current and related to historical and political events. This is essential for a first classification.

(2) Identity of the speaker: the position of the speaker 'as it relates to their authority or influence over their audience, in particular if they are a politician, public official, religious or community leader' ${ }^{40}$ It should be noted that the category of politicians is expressly indicated, precisely because of the power of dissemination of speech that the politician holds in society.

(3) Intent of the speaker to engage in advocacy to hatred: intent to 'target a protected group on the basis of a protected characteristic, and knowledge that their conduct will likely incite the audience to discrimination, hostility, or violence'.

39 ibid, 11.

40 ibid, 11 (emphasis added). 
In this case, the politician who hates is fully aware that his words will also help to bring other people to hate the same victims.

(4) Content of the expression: what 'was said, including the form and the style of the expression, and what the audience understood by this'. This is a complex aspect: it concerns the semantic interpretation of hate speech. The language of hate is among the most difficult to interpret because it does not necessarily contain vulgar expressions or explicit statements, but can also be conveyed with seemingly innocuous discourses (we refer to the 'cool' hate already known in the American tradition).

(5) Extent and magnitude of the expression: the 'public nature of the expression, the means of the expression, and the intensity or magnitude of the expression in terms of its frequency or volume'. As is known, the internet and social networks are today the most powerful tools available for spreading hate speech and reaching a very large number of people.

(6) Likelihood of harm occurring, including its imminence: there must be 'a reasonable probability of discrimination, hostility, or violence occurring as a direct consequence of the incitement'. ${ }^{41}$

This is, as we have seen, a very difficult point to interpret in practice. Individual national courts often elaborate parameters to try to develop homogeneous interpretations:

Consider protected characteristics. This point highlights states' obligations to

protect the right to equality more broadly, with an open-ended list of protected characteristics, supports an expansive interpretation of the limited protected characteristics in Article 20(2) of the ICCPR to provide equal protection to other individuals and groups who may similarly be targeted for discrimination or violence on the basis of other recognised protected characteristics. ${ }^{42}$

Provide proportionate sanctions. According to this point, the term 'prohibit by law' does not mean 'criminalization'; the HR Committee has said it only requires States to 'provide appropriate sanctions' in cases of incitement. 'Civil and administrative penalties will in many cases be most appropriate, with criminal sanctions an extreme measure of last resort. ${ }^{93}$

Finally, at the European level, the European Convention does not contain obligations for states to punish certain forms of expression, but the European Court of Human Rights (ECtHR) has recognized that certain forms of harmful expressions must be banned in order to achieve the overall (and general) objectives of the European Convention. At the same time, the Court monitors

\footnotetext{
ibid, 11.

ibid, 12 (emphasis added).

ibid, 12.
} 
the criminal sanctions imposed on these issues by states, to also assess the violation of the principle of proportionality. ${ }^{44}$

Council Framework Decision 2008/913/JHA of 28 November 2008 on combating certain forms and expressions of racism and xenophobia by means of criminal law is very interesting, too: it requires states to sanction certain hate expressions. The text of Article 1, in particular, is as follows:

Offences concerning racism and xenophobia

1. Each Member State shall take the measures necessary to ensure that the following intentional conduct is punishable:

(a) publicly inciting to violence or hatred directed against a group of persons or a member of such a group defined by reference to race, colour, religion, descent or national or ethnic origin;

(b) the commission of an act referred to in point (a) by public dissemination or distribution of tracts, pictures or other material;

(c) publicly condoning, denying or grossly trivialising crimes of genocide, crimes against humanity and war crimes as defined in Articles 6,7 and 8 of the Statute of the International Criminal Court, directed against a group of persons or a member of such a group defined by reference to race, colour, religion, descent or national or ethnic origin when the conduct is carried out in a manner likely to incite to violence or hatred against such a group or a member of such a group;

(d) publicly condoning, denying or grossly trivialising the crimes defined in Article 6 of the Charter of the International Military Tribunal appended to the London Agreement of 8 August 1945, directed against a group of persons or a member of such a group defined by reference to race, colour, religion, descent or national or ethnic origin when the conduct is carried out in a manner likely to incite to violence or hatred against such a group or a member of such a group.

2. For the purpose of paragraph 1, Member States may choose to punish only conduct which is either carried out in a manner likely to disturb public order or which is threatening, abusive or insulting.

3. For the purpose of paragraph 1, the reference to religion is intended to cover, at least, conduct which is a pretext for directing acts against a group of persons or a member of such a group defined by reference to race, colour, descent, or national or ethnic origin.

4. Any Member State may, on adoption of this Framework Decision or later, make a statement that it will make punishable the act of denying or grossly trivialising the crimes referred to in paragraph 1(c) and/or (d) only if the crimes referred to in these paragraphs have been established by a final decision of a national court of this Member State and/or an international court, or by a final decision of an international court only.

44 ibid, 12. 


\subsection{Hate Speech and the Online Framework}

Concerning the application of these principles to the online world, the authors of Article 19 reports highlight that at an international level, the UN Human Rights Council (HRC) recognized in 2012 that the 'same rights that people have offline must also be protected online'. The HR Committee has also 'made clear that limitations on electronic forms of communication or expression disseminated over the Internet must be justified according to the same criteria as non-electronic or "offline" communications' ${ }^{45}$

At the EU level, the E-Commerce Directive (Directive 2000/31/EC) requires that Member States

shield intermediaries from liability for illegal third party content where the intermediary does not have actual knowledge of illegal activity or information and, upon obtaining that knowledge, acts expeditiously to remove or disable access to the content at issue. The E-Commerce Directive prohibits Member States from imposing general obligations on intermediaries to monitor activity on their services. ${ }^{46}$

The limited shield from liability for intermediaries provided by the E-Commerce Directive

has been further undermined by the approach of the European Court. In Delfi AS v. Estonia, the Grand Chamber of the European Court found no violation of Article 10 of the European Convention where a national court imposed civil liability on an online news portal for failure to remove 'clearly unlawful' comments posted to the website by an anonymous third party, even without notice being provided. ${ }^{47}$

In extreme summary, the European Union's approach has been to leave providers exempt from liability for content that circulates on their platforms unless, with qualified reports, they were asked to remove specific content.

Today, this nonresponsibility approach is criticized because it is claimed that the provider is no longer just a content carrier, but has great ability to intervene on the content and to influence the dialogue on a platform. Many states are therefore seeking reform of this principle, which, in Europe, has been valid since the early 2000s.

Lastly, the 2016 European Commission's Code of Conduct on Countering Illegal Hate Speech, developed in collaboration with some of the major information technology companies, 'constitutes a (non-legally binding) commitment to remove "illegal hate speech", defined on the basis of the Framework 
Decision on Combatting Certain Forms and Expressions of Racism and Xenophobia by Means of Criminal Law, within 24 hours' ${ }^{48}$

In our humble opinion, codes of conduct are very interesting as political and awareness-raising projects, but they risk losing all effectiveness if the parties do not really commit themselves to applying them, and they often lack transparency. When very large operators are involved in such initiatives, it becomes very difficult to reach a common agreement and, subsequently, to concretely implement the principles of that agreement. Having said that, recent evaluations considering the effects of this specific Code in Europe seem to present very good results. ${ }^{49}$

\section{ONLINE POLITICAL HATE AND THE DIGITAL SOCIETY IN TULKENS' THOUGHT}

\subsection{Hate Speech and Politics}

The argument regarding the crucial relationship between political hatred and the online digital environment in Europe - especially if political hatred is conveyed through social network platforms - is the subject of a number of very accurate recent studies. The attention paid by many highly influential scholars increased, in particular, when the spread of electronic commerce in the European Union raised initial social, technological and legal questions. The internet, and its most important platforms, soon evolved into a data society and into a personal data market (and trade).

The worldwide success of Facebook, Twitter and other social networks, the crisis in traditional information systems (above all, of printed newspapers) and the daily use of smartphones - the most powerful personal communication tool for politicians today - have brought the consequence that even political activity engaged with this new means of communication. Political activity merged with the digital society and its mechanisms.

Françoise Tulkens, the Belgian former Vice-President of the European Court of Human Rights, is a criminal law scholar and a politician who has been consistently attentive to the evolution of political expressions of hatred in Europe. In a statement at a conference on this issue, ${ }^{50}$ she was very specific about the relationship between hate speech, (new) media and politics, and highlighted two very important preliminary points:

\footnotetext{
48 ibid, 15.

49 See Chapter 3, Paragraph 1.

50 See Françoise Tulkens, 'The hate factor in political speech: Where do responsibilities lie?' (The hate factor in political speech conference, Warsaw, 18-19 September 2013) <https://rm.coe.int/16800c170e> accessed 8 August 2019.
} 
The internet is not separate from social life (also) from a hate speech point of view and hate is strictly connected to the modern digital economy. Concerning this first point, a proper understanding of hate speech in media and public debate, according to Tulkens,

involves moving away from thinking about 'old' and 'new' media, or the internet as separate from social life and mainstream media. Instead, thinking about the impact of what has recently been called 'hybrid media' is more fruitful. By examining the inter-relations between political actors, media institutions and new practices of participatory communication, we can start to examine how extreme speech is (a) in part a product of accelerated competition for public attention, and as such, is shaped by identifiable practices and rituals of communication (b) that 'hate speech' has an economic value in a media environment shaped by intensive competition for clicks, hits and 'interaction' and that (c) the public contest over what can and cannot be said, a contest often organized around instances of extreme speech, has become a central tactic in and dimension of political positioning in contemporary societies. ${ }^{51}$

In our opinion too, hatred is only one element, albeit significant, of a more complex picture that has been created thanks to the convergence of the media, the presence of citizens on social networks and the change in methods of undertaking political activity.

Political parties and politicians have a specific responsibility, and must self-regulate. According to Tulkens, 'political parties and politicians have also not only a role but a social responsibility to restrain and avoid any discriminatory language and hate speech. Here it is above all a question of self-regulation. ${ }^{52}$ She is right. After initially timid approaches aimed only at identifying, for example, potential donors and financiers during electoral campaigns, or maintaining contact with voters and interest groups in the suburbs or in remote regions, the use of digital platforms, hybrid media, online tools and social networks for political purposes has visibly increased in intensity in Europe as elsewhere.

The political world is in fact interested today in the profiling of citizens, in attempts to 'anticipate' and predict their vote, in the conditioning of their thought during electoral contexts, in the circumvention of the traditional means of communication (and their filters) with live broadcasts and in the creation of teams able to manage the presence of the politician himself on social networks, as well as to promote the 'electronic body' of the candidate. In a political framework that is in many states characterized by permanent electoral campaign activity, with a sort of 'continuous electoral round', online hatred is spread like a currency.

ibid 6-7 (emphasis added).

52 ibid 7 (emphasis added). 
Political hate speech online can use the most important characteristics of the network and of the digital platforms in two precise directions: to foment aggregation and consensus towards the politicians' supporters, and to ridicule or attack political opponents in order either to take electoral advantage, or simply to satisfy voters.

Tulkens highlights, correctly, the following five consequential crucial points in a similar online political discussion based on hate. We will briefly comment on each point under the headings that follow.

\subsection{The Incorporation of Hate in European Political Discourses}

According to Tulkens, hate speech targeting ethnic, religious and sexual minorities, immigrants and other groups is a widespread phenomenon within Europe, including in political discourse. The scholar states that hate speech

is increasingly found not only in the political discourse of far-right parties, but spreads also into the rhetoric of mainstream parties. Populism does not relate only to countries under situations of austerity: today there is a new phenomenon of populism in Europe. A serious concern is the growing success of populist parties that widely use hate speech, as well as trivializing its use. Moreover, hate speech can be instrumental in increasing the voter base - cynical but effective. The mobilizing effect of populism and scapegoating is often accompanied by conspiracy theories. ${ }^{53}$

This first point is quite clear: the discourse of hatred has spread throughout the entire political sphere, and is used as a means by which to try to collect the greatest number of votes. In our opinion, hatred has become, for the political world, a real currency.

\subsection{The Dangers of the Prohibition of Political Discourses in a Democratic Society}

Tulkens states that political effort to limit hate speech 'has its dangers not only because it may encroach on freedom of expression but also because it could be misused as a tool for intimidating and containing opposition' ${ }^{54}$ This means that it is very important, from a political - and a legislative - point of view, to think seriously about what kind of hate speech is actually prohibited, particularly in political discourse, and which ideas must be considered too dangerous or too offensive to be included in the public discourse. ${ }^{55}$

ibid 4 (emphasis added).

ibid 4.

ibid 4. 
This is, in our opinion, also a very difficult aspect to resolve from a legislative point of view, because in all opinion crimes the line between just punishment of expressions that are genuinely hateful and the application of censorship methods is very subtle.

\subsection{Politicians and Their Position of Authority}

A fundamental point is the fact that, in Tulkens' thought, there are two specific characteristics of politicians' activities in the political debate that are really important. The first is that 'politicians and other public figures have a greater responsibility because they have broader possibilities for spreading prejudice against certain groups'. ${ }^{56}$ The second is that the impact of political speech is also greater because politicians are in a position of authority: so 'hate speech has an impact on potential offenders who feel encouraged in their intolerance and bias. In some countries, it has been said that criminal legislation has an added responsibility if the author of hate speech holds public office. ${ }^{57}$

\subsection{Silence Is Not Good}

In Tulkens' thought, it becomes fundamental, at a political level, to speak out. She correctly states that 'unless politicians speak out against hate speech by fellow politicians, silence can be interpreted as an approval'. ${ }^{58}$

It would also be essential to promote a 'climate' where diversity is a value:

we need to have a political culture in Europe where these issues and statements are addressed more firmly. As the European Court of Human Rights repeatedly said, diversity is not to be 'perceived as a threat but as a source of enrichment'. More precisely, in the functioning of political parties, diversity should be promoted in their leadership. ${ }^{59}$

This observation is correct. In its practical application, however, there are two concrete problems.

The first is that not many politicians openly fight hatred on the net. The second is that, in any case, the politician who hates is much more visible than the one who tries to make calm speeches or who decides to rebel against this kind of dialogue. It is sufficient to observe the guests who are invited on to

\footnotetext{
ibid 4 (emphasis added).

ibid 4.

ibid 4.

ibid 5 (emphasis added).
} 
political shows on television, who are often chosen precisely because of their ability to ignite a violent debate.

\subsection{Hate Speech Is Not an Isolated Social Phenomenon}

Finally, according to Tulkens, hate speech is not only inspired by some social circumstances or related to some political events, but is also an important part of a general democratic process.

As she writes, taking this observation seriously, it would be a fatal error to treat hate speech 'in isolation from a wider critique of racism, xenophobia, misogyny or homophobia in society. Hate speech is not a pathological exception to otherwise properly functioning public spheres. ${ }^{90}$

In fact, we believe the entire public sphere is today conditioned by the spread of online hatred.

\section{THE MAIN RESEARCH AREAS OF THIS WORK}

This work will deal with several major areas of research. First, we will try to understand if a link exists between the current political hatred online and the tradition of political hatred in Europe conveyed with nondigital means. ${ }^{61}$ Second, we will try to identify the most commonly used methods to convey hatred online, especially using the amplification and viral/sharing power allowed by the internet. ${ }^{62}$ Third, we will highlight several possible remedies to the current situation. ${ }^{63}$

However, some premises are necessary. We anticipated the fact that the European framework, as regards the subject of hatred, would be very peculiar, especially when compared to the US. These particularities are due to European historical traditions, especially the bloody events of the twentieth century; the (strong) importance in the US legal doctrine of First Amendment principles, which have always created a freer environment for the most extreme forms of expression; ${ }^{64}$ and the fact that most of the data of European citizens are processed by US platforms. This last point has led to friction between a well-defined European regulatory framework and some large platform

\footnotetext{
60 ibid 5-6.

61 See Chapters 2, 3, 4 and 7.

62 See Chapters 8, 9, 10 and 11.

63 See Chapter 10.

64 Concerning the most extreme expressions (especially white supremacy debates) and the First Amendment's principles, see Richard Delgado and Jean Stefancic, Must We Defend Nazis? Why the First Amendment Should not Protect Hate Speech and White Supremacy (New York University Press 1997).
} 
policies that allow greater margins of freedom to hate speech. This is why, in order to make an accurate study of the phenomenon of online political hatred in Europe, it is necessary to proceed by steps.

We are convinced, by the way, that it is not possible to understand the precise picture of online hatred in Europe today without accurate knowledge of the social and historical framework of the past hundred years. In the first place, it will be necessary to identify the category of political hatred typical of the European tradition, to assess whether it presents itself with original connotations and how it is conditioned by historical events which occurred during and after the Second World War. We need to verify, in other words, if there could be a 'European connotation' of expressions of hatred that could help the interpreter to highlight the most original aspects of this phenomenon.

Second, it will be necessary to analyse concrete cases in several European countries to understand whether, in practice, the phenomenon of online political hatred is becoming an urgent issue, also making reference to the legal principles of the European Union and international charts.

Subsequently, it will be important to assess which characteristics of the network today allow greater visibility and diffusion of political hate, and an increase in its level of harmfulness and influence on electoral contexts. Here we will also deal with hatred disseminated through disinformation and misinformation, and we will evaluate the ease with which false news can be spread on the internet. ${ }^{65}$ The analysis of the characteristics of the network will lead to the need to assess whether rules for platform control and regulation of political communication may be necessary, and if regulatory reform is an urgent matter.

All these issues are linked to a very delicate point: politicians' communication activities are directly related to the exercise of rights protected by almost all constitutional charts. We will see, in fact, that political speech is one of the most critical types of speech to regulate.

Finally, with reference to the remedies, to a possible improvement of the situation and of the method of doing politics, we will evaluate three aspects.

The first is that of education in the use of technology by politicians, and of counternarrative, digital civic education and legality, first because the politician must act as an example, and second because the politician has a lot of media power and influence (we will see that the hybrid case of "politician/ influencer' is very common today). ${ }^{66}$

The second is the reaction of the law. We will try to understand what the limit is, or if it is possible to identify a limit, for a reaction by a state that, on the one hand, wants to protect the weak and the victims of oppression, subordi-

See Chapter 11.

66 See Chapter 9, Paragraph 2. 
nation, discrimination, domination, harassment and marginalization ${ }^{67}$ and, on the other, does not want to implement censorship activities, or force platforms to censor content. ${ }^{68}$

Finally, we will reflect on possible technological solutions that could force platforms to activate automated systems for the management of the most critical, or clear, cases, and how technology could comply with the varying traditions, histories and values of different countries. ${ }^{69}$

The subject of political hatred, we will see, comes to include all kinds of hatred that the European legal tradition has always wanted to fight: religious hatred $;^{70}$ race-based hatred; homophobic hatred; hatred that aims to discriminate, dehumanize, mock or demean the victim. The messages conveyed today by the most extreme politicians concern, in fact, all these aspects.

The study, in several parts, will draw an overview of the political hate speech events that are occurring in Europe, even though it will inevitably be necessary to refer often to the North American legal doctrine, ${ }^{71}$ given, as we said, the presence of the main digital platforms in the US legal framework.

For reasons of space, we will not analyse all European states. We will focus on those states from which it is possible to draw useful ideas to help us in our research, trying to cover all areas and the new extremist political realities and trends.

${ }^{67}$ Concerning the necessary protection of the weak and of minority groups see Mary Kate Mc Gowan, Just Words: On Speech and Hidden Harm (Oxford University Press 2019).

68 Regarding, for example, the original, and innovative, connection between trademarks, privacy, personality rights and free speech, see Jacqueline Lipton, Internet Domain Names, Trademarks and Free Speech (Edward Elgar 2010).

69 Concerning the different traditions, and the different approaches, see Michael Herz and Peter Molnar, The Content and Context of Hate Speech: Rethinking Regulations and Responses (Cambridge University Press 2012).

70 Concerning religious hate speech, see Richard Moon, Putting Faith in Hate: When Religion Is the Source or Target of Hate Speech (Cambridge University Press 2018). For a precise reference to the European framework see, also, Erica Howard, Freedom of Expression and Religious Hate Speech in Europe (Routledge 2019). For an analysis about religious propaganda and freedom, see, in Italian, Jlia Pasquali Cerioli, Propaganda religiosa: la libertà silente (Giappichelli 2018).

${ }_{71}$ Regarding the relationships between freedom of speech and censorship, see Nadine Strossen, HATE: Why We Should Resist It with Free Speech, Not Censorship (Oxford University Press 2018). 